\title{
Tree community variation in a tropical continental island according to slope aspect and human interference
}

\author{
NATHAN B. GONÇALVES ${ }^{1}$, FELIPE C. NETTESHEIM ${ }^{2}$ and MARILENA M.S. CONDE ${ }^{3}$ \\ ${ }^{1}$ Environmental Dynamics Department, Brazil's National Institute for Amazon Research \\ - INPA, Av. André Araújo, 2936, 69067-375 Manaus, AM, Brazil \\ ${ }^{2}$ Programa de Pós-Graduação em Ecologia, CCS, Universidade Federal do Rio de \\ Janeiro, Ilha do Fundão, 21941-590 Rio de Janeiro, RJ, Brazil \\ ${ }^{3}$ Universidade Federal Rural do Rio de Janeiro, Departamento de Botânica, BR-465, Km 47, \\ Campus Universitário, Caixa Postal 74542, 23890-000 Seropédica, RJ, Brazil
}

Manuscript received on July 7, 2015; accepted for publication on March 18, 2016

\begin{abstract}
Associating description of unrecorded tropical tree community structure to sampling approaches that can help determine mechanisms behind floristic variation is important to further the comprehension of how plant species coexist at tropical forests. Thus, this study had the goals of (i) evaluating tree community

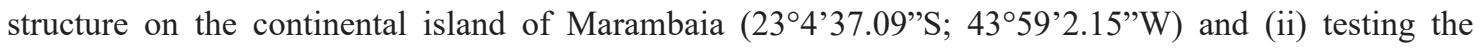
prediction that there are local scale changes in a tropical tree community structure between slopes facing different geographic orientation and with distinct human interference history. We established 60 (0.6 ha) sampling units in three different slope sites with distinct predominant geographic orientation and human interference. We sampled all woody trees with diameter at breast height $(\mathrm{dbh}) \geq 5 \mathrm{~cm}$. We found a total of 1.170 individuals representing 220 species, 120 genera and 50 families. The overall tree community structure and structural descriptors (abundance of individuals, basal area, species richness and diversity) varied extensively between the sites. The evidence presented here supports that local scale topography variations and human interference history can be important factors contributing to the known floristic heterogeneity of the Atlantic Rainforest. Future work on the study area should focus on disentangling effects from distinct causal factors over tree community variation and species occurrence.
\end{abstract}

Key words: anthropic impacts, Atlantic Rainforest, plant diversity, floristic variation, topography.

\section{INTRODUCTION}

Brazil is home to about one-sixth of the world's plant species richness and its flora is considered one of the most diverse on the planet (Myers et al. 2000). The Atlantic Rainforest plays a key role in this context regardless of being mostly reduced to different sized forest fragments. The relevance of the

Correspondence to: Nathan Borges Gonçalves

E-mail: nathanborges@gmail.com
Atlantic Rainforest has been mostly attributed to the high species richness and high levels of endemism together with a reduced area of original forest cover and a constant anthropogenic pressure (Myers et al. 2000, Conservation International 2014). This suggests that remnants of Atlantic Rainforest are excellent study areas to elucidate mechanisms behind plant species coexistence and assembly of tropical forest plant communities. Quantitative and qualitative studies that generate basic information 
about the occurrence and abundance of species in tropical forest landscapes are a vital first step in this regard (Moro and Martins 2011). The number of efforts with descriptive approaches in the Atlantic Rainforest increased in the last two decades and allowed a better comprehension of the factors governing plant community variation in this tropical forest (Oliveira-Filho and Fontes 2000, Nettesheim et al. 2010, Bertoncello et al. 2011, Bergamin et al. 2012). However, there are still many relevant Atlantic Rainforest remnants that have not yet been comprehensively evaluated and may bring new information to advance our knowledge of tropical forests.

Many of the biggest and most contiguous Atlantic Rainforest remnants are found on mountain ranges along the Brazilian coastline. The rough and steep terrain of such geological formations helped its preservation by imposing access limitations that inhibited the past exploration of this vegetation (Dean 1996). These remnants hold the richest forest formation of the Atlantic Rainforest, known as the Dense Ombrophylous Forest henceforward Atlantic Dense Ombrophylous Forest (Scarano 2002, Werneck et al. 2011, IBGE 2012). Families Myrtaceae, Fabaceae, Lauraceae, Rubiaceae, Euphorbiaceae and Sapotaceae are generally recorded as the richest and most important tree families in areas covered by this forest (Oliveira-Filho and Fontes 2000, Kurtz and Araújo 2000, Rochelle et al. 2011, Nettesheim et al. 2012). Furthermore, remnants are also typically characterized by a high number of tree species represented by occurrence of few individuals (Whitmore 1990, Kurtz and Araújo 2000, Scudeller et al. 2001, Rochelle et al. 2011). These floristic patterns denote the high tree community heterogeneity that is repeatedly detected as low similarity coefficients between different Atlantic Dense Ombrophylous Forest areas (OliveiraFilho and Fontes 2000, Kurtz and Araújo 2000, Nettesheim et al. 2010). Understanding what drives tree community variation of this forest on mountainous locations can provide important new insights to further develop theories seeking to explain community assembly in tropical forests.

Evidence indicates that tree community variation of the Atlantic Dense Ombrophylous Forest is affected by the topography changes found within the territory covered by this vegetation. Such topography heterogeneity appears to influence environmental factors that are important to the establishment and survival of plant species (Oliveira-Filho and Fontes 2000, Caiafa and Martins 2010, Nettesheim et al. 2010, Bertoncello et al. 2011, Bergamin et al. 2012, Guerra et al. 2013). The Serra do Mar mountain range is a typical case of such scenario. This landscape is covered by Atlantic Dense Ombrophylous Forest and it is found in a region regarded as a plant diversity hotspot within the Atlantic Rainforest hotspot (Murray-Smith et al. 2009). It stretches across four Brazilian states, reaches an altitude of $2316 \mathrm{~m}$ and displays a highly variable terrain (Almeida and Carneiro 1998). Topography changes along this mountain range can be critical for the establishment of plant species by affecting factors such as water supply, nutrient availability, air temperature, air humidity and amount of sunlight incidence (Dubayah 1994, Ferreira et al. 2005, Oliveira et al. 2008, Aguilar et al. 2010, Gao et al. 2011). Differences of these factors within small distances may determine microhabitats which are likely to affect plant community variation of the Atlantic Dense Ombrophylous Forest across Serra do Mar mountain range (Jones et al. 2011). Nevertheless, efforts addressing tree community variation due to the heterogeneous topography of this region are surprisingly lacking.

Another factor known to affect tropical forests is the occurrence of anthropic activities (Tilman et al. 1994). Common consequences of deleterious past and present human interferences on tree communities are unbalancing the natural dynamics of its regeneration process and opening of gaps which favor a higher frequency of tree 
species that would otherwise be more discreetly present (Guedes-Bruni et al. 2006). Therefore, the long-standing relationship between tropical forests and humans has left its signature in community assembly (Seiferling et al. 2014). Very few Atlantic Rainforest remnants managed to evade this faith and most suffered some kind of human interference throughout history (Oliveira and Engemann 2011). Although the topography of Serra do Mar contributed to preserve the forest it was not enough to completely prevent such actions (Dean 1996). Hunting, extraction of heart Palm (Euterpe edulis Mart.) and selective logging are still some of the illegal and often executed activities in the vegetation covering this mountain range (Tonhasca Jr. 2005). Even though quantifying human imprints is still a challenge in ecology, overall comprehension of its importance is likely to benefit from efforts that acknowledge its existence and struggle to detect patterns potentially caused by this source of variation.

It is paramount that efforts try to combine the study of poorly known tropical forests sites with approaches that help elucidate processes driving tree community variation in them. The vegetation covering the tropical continental island of Marambaia seems to provide an ideal setting in this sense. This is one of several continental islands along the southeastern Brazilian coast that are part of the Serra do Mar mountain chain and used to be connected to the dryland portion before ocean levels rose during the quaternary (Souza et al. 2005). The Atlantic Dense Ombrophylous Forest on this site lies on a heterogeneous topography, was exposed to past human interferences, exhibits high tree species richness, but still has an undocumented tree structure (Nettesheim et al. 2012).

Our main goal was to evaluate the hypothesis that topography changes and human interference affect tropical tree community structure on a local scale. To do this we devised the objectives of (i) evaluating the tree community structure on the slopes of the continental island of Marambaia and (ii) evaluating if tree community structure varies between slopes facing different geographic orientation and with distinct human interference history. Existing data about the tree community floristic composition on the Marambaia island suggested that we should expect a well preserved tropical tree community structure regardless of any human interferences (Nettesheim et al. 2012). Likewise, another effort in the area (Nettesheim et al. 2014) together with known environmental changes between distinct slopes led us to expect that the considered local scale changes would determine detectable differences in the tree community structure.

\section{MATERIALS AND METHODS}

\section{STUDY LOCATION}

We evaluated the Atlantic Dense Ombrophylous Forest located on the slopes of the continental island of Marambaia (henceforward simply Marambaia island - 234'37.09''S; 4359'2.15'W). This island is located at the southern coast of Rio de Janeiro state in the municipality of Mangaratiba (Fig. 1). The Marambaia island is within the bounds of the Mangaratiba Environmental Protection Area and the UNESCO Atlantic Forest Biosphere Reserve (Rambaldi et al. 2003). Average local temperature ranges between $20.9^{\circ} \mathrm{C}$ and $26.9^{\circ} \mathrm{C}$. Average annual precipitation is $1237.7 \mathrm{~mm}$ (Mattos 2005). It has an approximate area of $42 \mathrm{~km}^{2}$ and its terrain reaches up to the $641 \mathrm{~m}$. The heterogeneous topography of the area and its position relative to the ocean favors changes both in levels of intercepted solar radiation and sea wind exposure experienced by its slopes (Dubayah 1994, Ferreira et al. 2005, Aguilar et al. 2010, Gao et al. 2011). Furthermore, its slopes exhibit different histories of anthropogenic interference despite being preserved by the armed forces since 1971 (Pereira et al. 1990, Silva et al. 2008, Yabeta and Gomes 2013). 


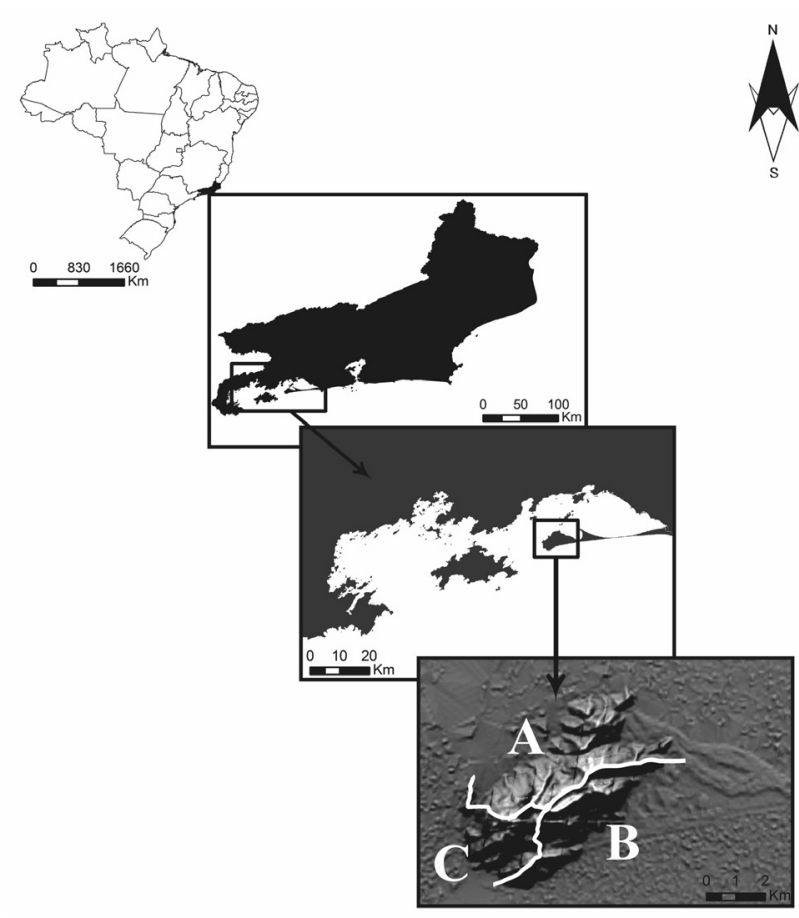

Figure 1 - Location of the continental island of Marambaia at the southern region of Rio de Janeiro state. White line over the terrain of the study area in the lower right image shows the three evaluated sites: (A) Northwest site; (B) Southeast site; (C) Southwest site.

\section{DATA SAMPLING}

The data was gathered between January 2004 and January 2013. We separated the topography of Marambaia island into three main groups of slopes (henceforward sites) to address our goals. Each of these sites has slopes with one predominant geographical orientation: slopes of site A face Sepetiba Bay and have a Northwest heading; slopes of site $\mathrm{B}$ face the Atlantic Ocean and have a Southeast heading; slopes of site $\mathrm{C}$ face Ilha Grande Island and have a Southwest heading (Fig. 1). We sampled the vegetation with sampling units that follow the specifications originally conceived by Alwyn H. Gentry (1982). Each sampling unit had dimensions of $2 \times 50 \mathrm{~m}$ and covered an area of $100 \mathrm{~m}^{2}$. We established 20 sampling units at each of the three sites at the study area $\left(2000 \mathrm{~m}^{2}\right.$ or 0.2 ha / site). Therefore, the vegetation at Marambaia island was evaluated through a total of 60 sampling units that comprised an area of 0.6 hectares $\left(6000 \mathrm{~m}^{2}\right)$. Sampling units had their location recorded with a GPSMAP Garmin 76 CSx. Our study focused on woody trees and included only individuals with diameter at breast height ( $\mathrm{dbh})$ of $5 \mathrm{~cm}$ or more. We tagged all sampled individuals, determined their species and estimated their height during field work. Specimens of each species were sampled to confirm their identification in the laboratory. The specimens collected were processed and thereafter deposited in the Herbarium of the Departamento de Botânica da Universidade Federal do Rio de Janeiro (RBR). We relied on the phylogeny provided by APG III (Bremer et al. 2009) and checked species names and authors with the International Plant Name Index (IPNI 2013).

\section{DATA ANALYSIS}

We started the analyses by tackling the initial goal of evaluating the tree community structure with a descriptive approach which simultaneously took into account the tree community at all three sites. This description of the tree community relied on calculating the phytosociological parameters of absolute and relative density ( $\mathrm{Rd}$ ), absolute and relative dominance (Rdom), absolute and relative frequency (Rf), and importance value (IV) (Mueller-Dombois and Ellenberg 1974, Martins 1993). Then we constructed the diameter distribution of individuals for the whole tree community on Marambaia island. Diameter classes were determined according to Spiegel's (1976) approach. We concluded these initial analyses by calculating tree community diversity and evenness with the Shannon-Wiener (H') and Pielou (J') indexes (Magurran 2004).

Next, we executed the analyses to determine if tree community structure varied between the sites. This was done with two techniques to address the tree community structure multivariate 
response and two additional tests that were used to complement one of the multivariate techniques and to address four more community structure univariate responses. We started by organizing a data matrix containing species abundance data in each sampling unit. This matrix was standardized through the Hellinger distance (Legendre and Gallagher 2001) and used to calculate a second matrix containing the similarity distance between pairs of sampling units. We calculated the similarity distances in the second matrix with the MorisitaHorn coefficient (Magurran 2004). Then we ran a Principal Coordinates Analysis (PCoA) using this similarity matrix to synthesize the tree community structure variation into orthogonal axes. We tested if tree community structure varied between sites $\mathrm{A}, \mathrm{B}$ and $\mathrm{C}$ by using a permutational ANOVA that compared the ordination of sampling units on each of the first two PCoA axes (Anderson and Legendre 1999). Pemutational ANOVA was chosen because tree community data did not meet all the parametric criteria of ANOVA. We applied the Games-Howell post-hoc test after the permutational ANOVAs in order to identify significant differences between the sites (Games and Howell 1976). Our decision to use the Games-Howell test was motivated by the fact that it is a conservative post-hoc test regarding type I and II errors (Armstrong et al. 2000). The Hellinger standardized species abundance matrix used to ultimately run PCoA was then submitted to an Indicator Species Analysis - ISA (Dufrêne and Legendre 1997) to determine which species were mostly associated to the tree community structure on each site. We further addressed if tree community changed in structure between the sites by comparing the univariate responses represented by species richness (henceforward richness), total abundance of individuals (henceforward abundance), total basal area (henceforward basal area) and the Shannon-Wiener diversity index (henceforward diversity) recorded in the sampling units. This was done by determining the values of each of these attributes in the sampling units and testing if their means differed between sites A, B and $\mathrm{C}$ with the permutational ANOVA (Anderson and Legendre 1999). The Games-Howell post-hoc test was then used to identify significant differences between the sites for each of these four community structure univariate responses.

We ran all statistical analysis in the $\mathrm{R}$ 3.1.0 environment ( $\mathrm{R}$ Core Team 2014). We conducted PCoA and ISA analyses with aid of packages Vegan (Oksanen et al. 2014) and labdsv (Roberts 2013). Permutational ANOVAs and GamesHowell post-hoc tests relied, respectively, on the code provided by P. Legendre (http://adn.biol. umontreal.ca/ numericalecology/Rcode/) and on a code developed based on the algorithm suggested by Games and Howell (1976).

\section{RESULTS}

TREE COMMUNITY STRUCTURE ON MARAMBAIA ISLAND

Tree community structure in the 60 sampling units was represented by a total of 1170 individuals. These comprised a basal area of $31.50 \mathrm{~m}^{2}$ and were divided into 220 species, 118 genera and 50 families (see the Supplementary Material - Table SI). We estimated a basal area and total abundance of 50.85 $( \pm 6.92) \mathrm{m}^{2} /$ ha and $2105( \pm 185)$ individuals/ha, respectively. We encountered an exponential decay pattern in the diameter distribution of the sampled individuals (see Fig. S1). In other words, there was a greater number of individuals in the first diameter distribution class (54.78\%) followed by a decreasing number of individuals in progressively larger diameter classes. Shannon diversity index for the whole tree community was $H^{\prime}=4.66$ nats/ ind and the Pielou evenness index was J' $=0.86$.

The species with greater IV in the tree community (Table I) were Guapira opposita (Vell.) Reitz (25.78), Chrysophyllum flexuosum Mart. (11.06), Vochysia oppugnata Warm. (10.06), 
TABLE I

Structural parameters for the ten species with highest importance value in the Atlantic Rainforest tree community on the continental island of Marambaia. The full list of the detected species and their structure descriptors can be seen in Table SII. Ni = number of individuals; $R d=$ Relative density; $R f=$ Relative frequency; $R d o m=$ Relative dominance; $I V=$ Importance value.

\begin{tabular}{cccccc}
\hline Species & Ni & Rd & Rf & Rdom & IV \\
\hline Guapira opposita (Vell.) Reitz & 111 & 9.49 & 4.33 & 11.97 & 25.78 \\
Chrysophyllum flexuosum Mart. & 42 & 3.59 & 2.97 & 4.50 & 11.06 \\
Vochysia oppugnata Warm. & 24 & 2.05 & 2.10 & 5.90 & 10.06 \\
Eriotheca pentaphylla (Vell. emend. K.Schum.) A.Robyns & 20 & 1.71 & 1.36 & 5.59 & 8.66 \\
Sorocea bonplandii (Baill.) W.C.Burger et al. & 42 & 3.59 & 2.47 & 2.40 & 8.46 \\
Pseudopiptadenia contorta (DC.) G.P.Lewis \& M.P.Lima & 22 & 1.88 & 1.85 & 4.00 & 7.73 \\
Senefeldera verticillata (Vell.) Croizat & 41 & 3.50 & 2.10 & 1.64 & 7.25 \\
Ocotea schottii (Meisn.) Mez & 27 & 2.31 & 2.10 & 2.43 & 6.84 \\
Brosimum guianense (Aubl.) Huber & 34 & 2.91 & 2.60 & 1.11 & 6.61 \\
Nectandra oppositifolia Nees \& Mart. & 17 & 1.45 & 1.36 & 2.97 & 5.78 \\
\hline
\end{tabular}

TABLE II

Structural parameters for the ten families with highest importance value in the Atlantic Rainforest tree community on the continental island of Marambaia. The full list of the detected families and their structure descriptors can be seen in Table SIII. Ni = number of individuals; $R d=$ Relative density; $\mathbf{R f}=$ Relative frequency; $\mathbf{R d o m}=$ Relative dominance; IV $=$ Importance value.

\begin{tabular}{|c|c|c|c|c|c|}
\hline Family & $\mathrm{Ni}$ & $\mathrm{Rd}$ & $\mathrm{Rf}$ & Rdom & IV \\
\hline NYCTAGINACEAE & 111 & 9.49 & 5.92 & 11.97 & 27.38 \\
\hline SAPOTACEAE & 107 & 9.15 & 7.28 & 10.95 & 27.37 \\
\hline MYRTACEAE & 151 & 12.91 & 7.78 & 5.59 & 26.28 \\
\hline FABACEAE & 77 & 6.58 & 6.09 & 9.61 & 22.28 \\
\hline LAURACEAE & 80 & 6.84 & 6.60 & 7.03 & 20.47 \\
\hline MORACEAE & 91 & 7.78 & 6.26 & 5.15 & 19.18 \\
\hline EUPHORBIACEAE & 59 & 5.04 & 4.06 & 3.24 & 12.34 \\
\hline RUBIACEAE & 54 & 4.62 & 5.08 & 1.91 & 11.60 \\
\hline MALVACEAE & 28 & 2.39 & 2.71 & 5.91 & 11.01 \\
\hline VOCHYSIACEAE & 24 & 2.05 & 2.88 & 5.90 & 10.83 \\
\hline
\end{tabular}

Eriotheca pentaphylla (Vell. emend. K.Schum.) A.Robyns (8.66) and Sorocea bonplandii (Baill.) W.C.Burger et al. (8.46). These five species represented $20.42 \%$ (239 individuals) of the sampled individuals and answered for $21.24 \%$ of the total tree community IV (see Table SII). Species represented by only one individual were $32.18 \%$ (72 spp.) of the recorded species. The families with highest IV in the tree community (Table II) were Nyctaginaceae (27.38), Sapotaceae (27.37),
Myrtaceae (26.28), Fabaceae (22.28) and Lauraceae (20.47). These families together comprised $44.95 \%$ (526 individuals) of the sampled individuals and $41.26 \%$ of the IV (see Table SIII).

\section{TREE COMMUNITY VARIATION ACROSS LOCAL SCALE TOPOGRAPHY}

Final PCoA ordination showed that the floristic and structure of the tree community changes between sites A, B and C (Fig. 2). Our tests confirmed the 


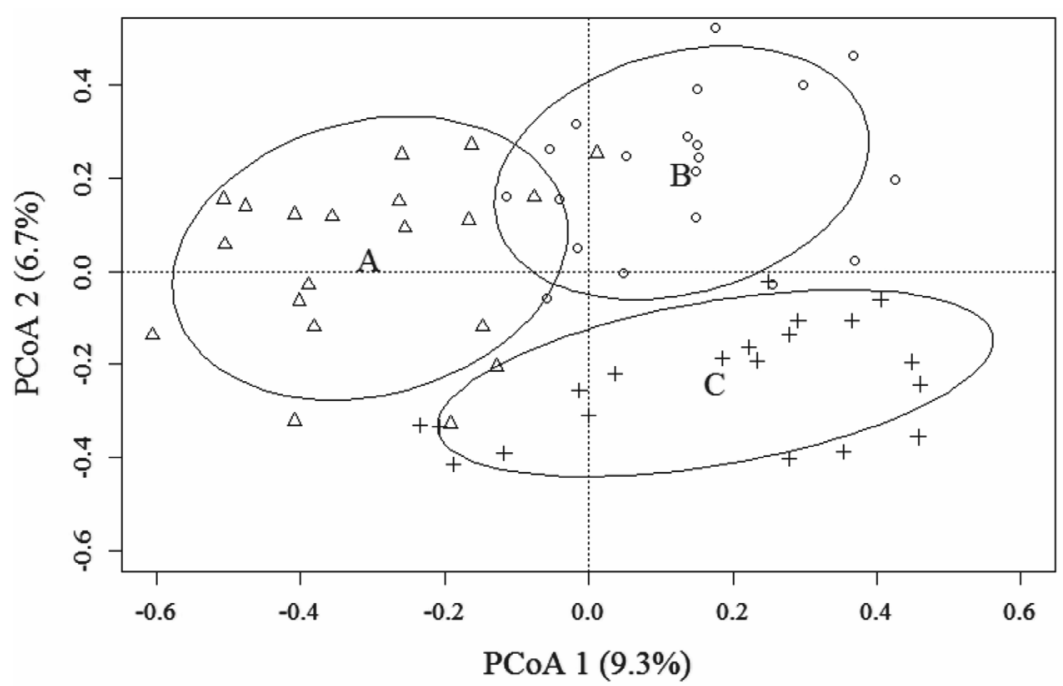

Figure 2 - Final Principal Coordinates Analysis (PCoA) ordination of the tree community composition and structure on the continental island of Marambaia. Triangles represent the sampling units established at the site A (Northwest), circles represent the sampling units established at site B (Southeast) and crosses represent the sampling units established at site C (Southwest). Axis one captured $9.3 \%$ of the tree community variation and axis two captured other $6.7 \%$ of the variation.

existence of this tree community differentiation pattern for the first $(\mathrm{F}=39.88 ; \mathrm{P}=0.001)$ and second $(\mathrm{F}=41.52 ; \mathrm{P}=0.001)$ axes of the ordination. The first PCoA axis showed that tree community structure differs between sites $\mathrm{A}$ and $\mathrm{B}(\mathrm{t}=8.53$; df = 37.9; $\mathrm{P}<0.001)$ and between sites $\mathrm{A}$ and $\mathrm{C}(\mathrm{t}=$ 7.54; $\mathrm{df}=34.3 ; \mathrm{P}<0.001)$, but not between sites $\mathrm{B}$ and $\mathrm{C}(\mathrm{t}=0.75 ; \mathrm{df}=33.3 ; \mathrm{P}=0.74)$. The second $\mathrm{PCoA}$ axis showed that tree community structure differs between sites $\mathrm{A}$ and $\mathrm{B}(\mathrm{t}=3.35$; $\mathrm{df}=37.5$; $\mathrm{P}=0.005)$, sites $\mathrm{A}$ and $\mathrm{C}(\mathrm{t}=5.48 ; \mathrm{df}=32.9 ; \mathrm{P}<$ $0.001)$ and sites $\mathrm{B}$ and $\mathrm{C}(\mathrm{t}=9.95 ; \mathrm{df}=34.9 ; \mathrm{P}<$ $0.001)$.

Although the variation of tree community structure captured by each PCoA axis was low, the changes between sites A, B and C were further corroborated by all subsequent analyses. Tree community structure variation between the sites allowed detection of 14 indicator species for site A, nine indicator species for sites $B$ and seven indicator species for site C (Table III). Additionally, tree community structure differs between the sites with regard to abundance $(\mathrm{F}=31.55 ; \mathrm{P}=0.001)$, richness $(\mathrm{F}=11.9 ; \mathrm{P}=0.001)$, basal area $(\mathrm{F}=11.0$; $\mathrm{P}=0.001)$ and diversity $(\mathrm{F}=6.14 ; \mathrm{P}=0.005)$. Tree abundance was different between all three sites (Fig. 3). It decreased from site A to site B and then to site $\mathrm{C}$. On the other hand, richness, diversity and basal area were equivalent in sites $\mathrm{A}$ and $\mathrm{B}$ and greater than in site $\mathrm{C}$ (Fig. 3). Our analysis did not detect differences for these last three attributes between sites A and B (see Table SIV).

\section{DISCUSSION}

In this study we bring comprehensive descriptive data regarding the tree community structure of an Atlantic Dense Ombrophylous Forest location where only tree composition was previously recorded (Nettesheim et al. 2012). The information here corroborates our initial expectation that this remnant is in overall advanced natural regeneration stage and is a relevant representative of the fragmented Atlantic Rainforest due to its high species richness and diversity values. Furthermore, 
TABLE III

Indicator species detected by the Indicator Species Analysis (ISA) for sites A (Northwest), B (Southeast) and $C$ (Southwest) of the continental island of Marambaia. iv $=$ indicator value; $\boldsymbol{P}=$ probability from permutation test to evaluate significance of the indicator value.

\begin{tabular}{|c|c|c|c|}
\hline Indicator species & Site & iv & $P$ \\
\hline Guapira opposita (Vell.) Reitz & A & 54.83 & 0.001 \\
\hline Vochysia oppugnata Warm. & A & 49.13 & 0.001 \\
\hline $\begin{array}{c}\text { Pseudopiptadenia contorta (DC.) } \\
\text { G.P.Lewis \& M.P.Lima }\end{array}$ & A & 40.17 & 0.001 \\
\hline $\begin{array}{c}\text { Nectandra oppositifolia Nees \& } \\
\text { Mart. }\end{array}$ & A & 38.12 & 0.001 \\
\hline $\begin{array}{l}\text { Cybistax antisyphilitica } \\
\text { (Mart.).Mart }\end{array}$ & A & 35.00 & 0.002 \\
\hline Myrcia splendens (Sw.) DC.s & A & 33.04 & 0.012 \\
\hline $\begin{array}{l}\text { Sparattosperma leucanthum } \\
\text { (Vell.) K.Schum. }\end{array}$ & A & 25.00 & 0.012 \\
\hline $\begin{array}{c}\text { Amaioua intermedia Mart. ex } \\
\text { Schult. \& Schult.f. }\end{array}$ & A & 24.98 & 0.014 \\
\hline Mollinedia oligantha Perkins & A & 20.55 & 0.046 \\
\hline Tabernaemontana laeta Mart. & A & 20.35 & 0.037 \\
\hline Casearia arborea (Rich.) Urb. & A & 20.00 & 0.036 \\
\hline Cordia trichoclada A.DC & A & 20.00 & 0.032 \\
\hline Cupania oblongifolia Mart. & A & 20.00 & 0.028 \\
\hline Eugenia umbelliflora O.Berg & A & 20.00 & 0.024 \\
\hline $\begin{array}{l}\text { Sorocea bonplandii (Baill.) } \\
\text { W.C.Burger et al. }\end{array}$ & B & 47.90 & 0.001 \\
\hline Chrysophyllum flexuosum Mart. & B & 30.29 & 0.043 \\
\hline $\begin{array}{c}\text { Brosimum guianense (Aubl.) } \\
\text { Huber }\end{array}$ & B & 28.31 & 0.045 \\
\hline Coussarea accedens Müll.Arg. & B & 26.79 & 0.014 \\
\hline $\begin{array}{c}\text { Myrcia racemosa (O.Berg) } \\
\text { Kiaersk. }\end{array}$ & B & 25.00 & 0.008 \\
\hline Myrcia pubipetala Miq & B & 25.00 & 0.010 \\
\hline Myrcia sp. 2 & B & 20.00 & 0.036 \\
\hline Pouteria sp. 1 & B & 20.00 & 0.029 \\
\hline $\begin{array}{c}\text { Schefflera angustissima (Marchal) } \\
\text { Frodin }\end{array}$ & B & 20.00 & 0.031 \\
\hline $\begin{array}{l}\text { Anaxagorea dolichocarpa } \\
\text { Sprague \& Sandwith }\end{array}$ & $\mathrm{C}$ & 31.24 & 0.003 \\
\hline $\begin{array}{c}\text { Senefeldera verticillata (Vell.) } \\
\text { Croizat }\end{array}$ & $\mathrm{C}$ & 31.03 & 0.009 \\
\hline Couepia schottii Fritsch & $\mathrm{C}$ & 30.00 & 0.002 \\
\hline Pouteria aff. macrophylla & $\mathrm{C}$ & 25.00 & 0.009 \\
\hline Inga capitata Desv. & $\mathrm{C}$ & 21.95 & 0.044 \\
\hline Chrysophyllum aff. inornatum & $\mathrm{C}$ & 20.00 & 0.041 \\
\hline Esenbeckia grandiflora Mart. & $\mathrm{C}$ & 20.00 & 0.032 \\
\hline
\end{tabular}

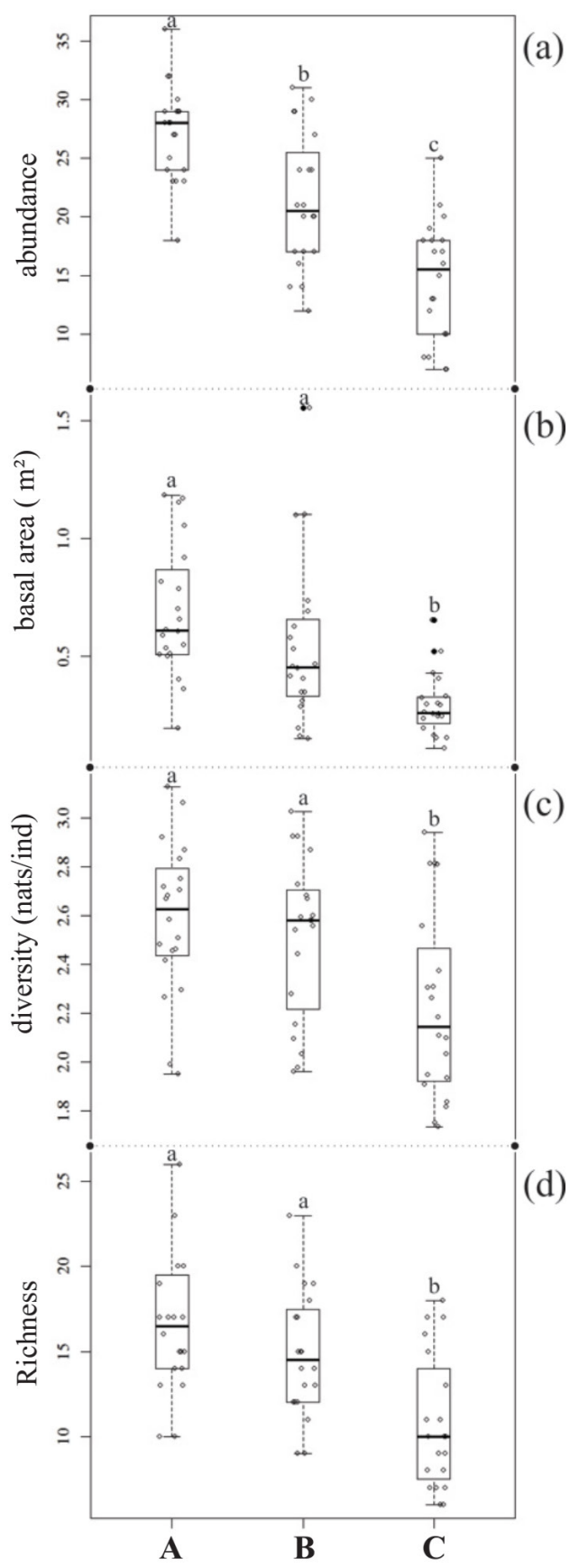

Figure 3 - Comparison of Atlantic Dense Ombrophylous Forest tree community (a) abundance of individuals, (b) total basal area, (c) species diversity and (d) richness between sites $\mathrm{A}, \mathrm{B}$ and $\mathrm{C}$ on the continental island of Marambaia. White circles represent the dispersion of the raw data for each site and black circles represent outlier values. Letters a, b and c over dispersion bars of the boxplots show results of the GamesHowell post-hoc test that compared mean values for each of these evaluated tree community attributes (See Table SIV). 
results here also represent evidence which confirm our second expectation that local scale topography variation and human interference can be associated to detectable tree community structure differences.

The tree community structure on Marambaia island indicates that this remnant is a well-preserved Atlantic Dense Ombrophylous Forest in advanced natural regeneration stage. Estimated values of basal area and abundance at the studied area are equivalent to those from Dense Ombrophilous Forests in advanced natural regeneration stage at the Estação Ecológica Estadual de Paraíso and in the neighbor island of Ilha Grande (Kurtz and Araújo 2000, Oliveira 2002). Although this comparison needs to be cautious due to the different sampling designs of these studies (Moro and Martins 2011), other results further support the above interpretation. The distribution of individuals in diameter classes showed a pattern typically found at well-preserved tropical forests. It indicates that the studied tree community does not appear to have natural regeneration problems. In addition, only a small number of the tree species achieved high IV, whereas the majority obtained low IV. The number of species with high IV in tree communities is usually low at Atlantic Dense Ombrophylous Forest remnants in advanced natural regeneration stage (Kurtz and Araújo 2000, Borém and Ramos 2001, Oliveira 2002, Santana et al. 2008, Rodrigues and Magalhães 2011). Lastly, the differences between the most important tree species detected in the structure of the community studied here and the most important found in the structure of other Dense Ombrophilous Forests corroborates the typical pattern of tree floristic variation expected for Atlantic Dense Ombrophylous Forest remnants (Kurtz and Araújo 2000, Oliveira 2002, Tabarelli and Montovani 1999, Oliveira-Filho and Fontes 2000, Rochelle et al. 2011). Additionally, the richness and diversity values reported here and in Nettesheim et al. (2012) for the forest on Marambaia island are also in agreement with this pattern.
They are amongst the highest species richness and diversity values recorded for the Atlantic Dense Ombrophylous Forest in the states of Rio de Janeiro and São Paulo (Kurtz and Araújo 2000, Nettesheim et al. 2010, Rochelle et al. 2011). Understanding the mechanisms behind the coexistence of this many tree species on the limited area of a tropical island can help to elucidate ecological processes operating tropical forest tree community variation both on smaller and greater scales.

Atlantic Rainforest tree community variation on larger scales has been chiefly related to environmental variation along the area covered by this vegetation. The heterogeneous terrain and latitudinal range over which this forest is found appear to promote environmental changes that affect the occurrence and persistence of tree species in the landscape (Oliveira-Filho and Fontes 2000, Scarano 2002, Nettesheim et al. 2010, Bertoncello et al. 2011, Bergamin et al. 2012, Oliveira-Filho et al. 2013). Our results confirm this trend and further support that the variation of terrain features such as slope geographic guidance in a small scale can help explain the high richness and variation found in tropical tree communities over heterogeneous topographies. It is likely that at least part of the detected tree community species turnover between the sites studied here results from the species abilities to cope with distinct amounts of sunlight incidence (Chase and Leibold 2003). Such interpretation is reinforced by the existence of a similar community structure and composition variation pattern also detected for the fern and lycophytes communities within the Atlantic Dense Ombrophylous Forest at Marambaia island (Nettesheim et al. 2014). In fact, tropical tree and fern communities have been documented to respond equally and mostly to environmental mechanisms than to stochastic ones (Jones et al. 2013). Together these evidences corroborate that topography heterogeneity can be an important source of environmental changes 
which contribute to tropical plant community structure variation in landscapes with rough terrain.

According to the present assessment one possible interpretation is that local scale topography heterogeneity may determine environmental changes abrupt enough to represent limiting habitats which affect tree community structure outcome. Changes in tree community structure shown by PCoA and ISA together with the lower values for abundance, basal area, richness and diversity on site $\mathrm{C}$ may result from a rockier and shallower soil at this site relative to sites A and B. There is both a higher incidence of exposed boulders and small rocks on site $\mathrm{C}$ and the vegetation is found altogether closer and above the only rocky shore of the island (personal in locus observation). Thus, the establishment and growth of tree species could be limited at site $\mathrm{C}$ when compared to the other two evaluated sites. Larger trees may not be as viable in areas with shallower and rockier soils because those that manage to establish eventually succumb as they grow bigger. Such situation can be particularly true if slopes are also steeper in site $C$ than in sites A and B (Oliveira et al. 2008). This would explain the lower values recorded for richness, diversity, abundance and basal area at site C. Such interpretation is further supported by the fact that sites A and B shelter tree richness, basal areas and diversities that are equivalent and consistently higher than at site $\mathrm{C}$.

Findings also suggest that human impacts may have also affected the patterns of tree community variation at the study area. Anthropogenic activities are capable of severely affecting the dynamics of natural ecosystems and their influence on the variation of tropical forests plant communities is increasingly evident (Solórzano et al. 2012, Seiferling et al. 2014). According to this reasoning, the higher abundance of individuals in site $\mathrm{A}$ than in sites $\mathrm{B}$ and $\mathrm{C}$ may extend beyond the discussed environmental effects to also represent the footprint of past anthropogenic disturbances.
The little available literature suggests that slopes in site A endured more extensive interferences in the past than slopes in sites B and C (Yabeta and Gomes 2013). Therefore, it is possible that the tree community structure found today on site $\mathrm{A}$ is at a younger natural regeneration stage than in site $\mathrm{B}$ regardless of the overall vegetation conservation status at the island. Consequently, the higher number of individuals that managed to establish due to openings provided by human interferences would still be competing to guarantee their survival in this the area (Oliveira 2002). Similarly, it is likely that at least part of the patterns we encountered for tree community structure at site $\mathrm{C}$ are further related to human activities that never completely ceased in this site (Silva et al. 2008, Yabeta and Gomes 2013). The caiçara population living in Marambaia island continues to rely on food and timber resources available in the nearby forest to supplement family resources. Site $\mathrm{C}$ holds the forest location closest to the caiçara's residences and at the same time farther from the Military Command Center that inhibits most negative anthropic activities. Limited entrance of propagules due to its remoteness as an island coupled with constant hunting and resource extraction without proper management seem likely to have hindered the life cycles of distinct tree species and ultimately affected tree community structure assembly at site $\mathrm{C}$. Therefore, it is paramount that relevancy of human effects on the assembly of tropical forest plant communities does not go overlooked, especially because natural landscapes free of human interference are almost inexistent (Seiferling et al. 2014).

The occurrence pattern of indicators in the tree community structure is evidence that species may have ecological preferences for each of the evaluated sites due to some sort of competitive advantage. Given the considerations in this study, it appears that possible advantages of these indicator species are related to topography driven environmental conditions, time of arrival during 
human interference in the successional process, or even overlooked complementary effects due to biotic interactions (Chase and Leibold 2003, Seiferling et al. 2014). Within this reasoning, it is likely that indicator species in site A are capable of coping better with higher levels of sunlight incidence and past human interference; those in site B thrive at lower levels of sunlight incidence while experiencing little human interference; and those in site $\mathrm{C}$ do better at shallow rocky and steeper soil while dealing with small continuous human interference. We encourage future studies to disentangle the contribution of environmental, historical and stochastic factors to explain the occurrence of these indicator species in the sites. Knowledge about the ecology of tropical tree species together with that of the tree community structure assembly processes in areas with heterogeneous topography can provide important insights for theories aiming to explain the coexistence of tree species in tropical forests (Hubbell 2001, Chase and Leibold 2003) and for decisions regarding its conservation and restoration (Rodrigues et al. 2011).

This study showed that the evaluated forest remnant is well-preserved and its tree community contributes to the floristic representativeness of the Atlantic Dense Ombrophilous Forest despite past and present human interferences. Our evidence proves that the tree community structure variation typically observed on regional scales can also be detected in local scales in an area exhibiting heterogeneous topography. Findings here corroborate that environmental changes favored by the rough terrain together with human actions appear decisive to shape tropical tree community structure on the local scale. Disentangling pure and joint effects of these and other factors over tree community assembly and species occurrence patterns on the continental island of Marambaia is an important next step to provide more information regarding mechanisms behind tropical forest variation on heterogeneous topography.

\section{ACKNOWLEDGMENTS}

We thank the Centro de Avaliação da Ilha da Marambaia (CADIM) and the Brazilian Navy for allowing entrance to the area and for providing logistic backup during field activities. We are also grateful for the institutional support of the Botanic Department of Universidade Federal Rural do Rio de Janeiro (UFRRJ) and for the various colleagues who helped during field activities. Finally, we thank Thiago A. Amorim, Daniel C. Carvalho and the taxonomists Ariane L. Peixoto, Haroldo C. de Lima, Maria de Fátima Freitas, Alexandre Quinet, Carine Quinet, Marcelo C. Souza, Genise V. Somner, Lucy S. Vale, Elsie F. Guimarães, Fernando Regis Di Maio, Ronaldo Marquete and Inês Cordeiro for the kindness in identifying botanic materials.

\section{REFERENCES}

AGUILAR C, HERRERO J AND POLO MJ. 2010. Topographic effects on solar radiation distribution in mountainous watersheds and their influence on reference evapotranspiration estimates at watershed scale. Hydrol Earth Syst Sci 7: 2373-2411.

ALMEIDA FFM AND CARNEIRO CDR. 1998. Origem e evolução da Serra do Mar. Bra J Geol 28: 135-150.

ANDERSON MJ AND LEGENDRE P. 1999. An empirical comparison of permutation methods for tests of partial regression coefficients in a linear model. J Stat Comput Sim 62: 271-303.

ARMSTRONG RA, SLADE SV AND EPERJESI F. 2000. An introduction to analysis of variance (ANOVA) with special reference to data from clinical experiments in optometry. Ophthal Physl Opt 20: 235-241.

BERGAMIN RS, MÜLLER S AND MELLO RSP. 2012. Indicator species and floristic patterns in different forest formations in southern Atlantic rainforests of Brazil. Community Ecol 13: 162-170.

BERTONCELLO R, YAMAMOTO K, MEIRELES LD AND SHEPHERD GJ. 2011. A phytogeographic analysis of cloud forests and other forest subtypes amidst the Atlantic forests in south and southeast Brazil. Biodivers Conserv 20: 3413-3433.

BORÉM RAT AND RAMOS DP. 2001. Estrutura fitossociológica da comunidade arbórea de uma 
toposseqüência pouco alterada de uma área de floresta atlântica, no município de Silva Jardim-RJ. Rev Arvore 25: 131-140.

BREMER B, BREMER K, CHASE M, FAY M, REVEAL J, SOLTIS D, SOLTIS P AND STEVENS P. 2009. An update of the Angiosperm Phylogeny Group classification for the orders and families of flowering plants: APG III. Bot J Linn Soc 161: 105-121.

CAIAFA AN AND MARTINS FR. 2010. Forms of rarity of tree species in the southern Brazilian Atlantic rainforest. Biodivers Conserv 19: 2597-2618.

CHASE JM AND LEIBOLD MA. 2003. Ecological niches: linking classical and contemporary approaches. Chicago: University of Chicago Press, 212 p.

CONSERVATION INTERNATIONAL. 2014. Hotspots. $<$ http://www.conservation.org/how/pages/hotspots.aspx $>$. Accessed 14 January 2014.

DEAN W. 1996. A ferro e fogo: a história e a devastação da Mata Atlântica brasileira. São paulo: Companhia das Letras, $484 \mathrm{p}$.

DUBAYAH RC. 1994. Modeling a solar radiation topoclimatology for the Rio Grande River Basin. J Veg Sci 5: 627-640.

DUFRÊNE MAND LEGENDRE P. 1997. Species assemblages and indicator species: the need for a flexible asymmetrical approach. Ecol Monogr 67: 345-366.

FERREIRA F, AZEVEDO AC, WAPPLER D, KANIESKI A, GIRELLI D AND PEDROTTI J. 2005. Exposição solar e propriedades do solo em Santa Maria-RS. Curr Agr Sci Technol 11: 377-381.

GAMES PA AND HOWELL JF. 1976. Pairwise multiple comparison procedures with unequal n's and/or variances: a Monte Carlo study. J Educ Behav Stat 1: 113-125.

GAO ZQ, LIU CS, GAO W AND CHANG NB. 2011. A coupled remote sensing and the Surface Energy Balance with Topography Algorithm (SEBTA) to estimate actual evapotranspiration over heterogeneous terrain. Hydrol Earth Syst Sc 15: 119-139.

GENTRY AH. 1982. Neotropical floristic diversity: phytogeographical connections between Central and South America, Pleistocene climatic fluctuations, or an accident of the Andean orogeny? Ann Mo Bot Gard 69: 557-593.

GUEDES-BRUNI RR, NETO SJS, MORIM MP AND MANTOVANI W. 2006. Composição florística e estrutura de trecho de floresta ombrófila densa atlântica aluvial na Reserva Biológica de Poço das Antas, Silva Jardim, Rio de Janeiro, Brasil. Rodriguésia 57: 413-428.

GUERRA TNF, RODAL MJN, LINS-E-SILVA ACB, ALVES M, SILVA MAM AND MENDES PGA. 2013. Influence of edge and topography on the vegetation in an Atlantic Forest remnant in northeastern Brazil. J For Res 18: 200-208.

HUBBELL SP. 2001. The unified neutral theory of biodiversity and biogeography. Princeton: Princeton University Press, $392 \mathrm{p}$.
IBGE - INSTITUTO BRASILEIRO DE GEOGRAFIA E ESTATÍSTICA. 2012. Manual Técnico da Vegetação Brasileira. <ftp://geoftp.ibge.gov.br/documentos/ recursos_naturais/manuais_tecnicos/manual_tecnico vegetacao_brasileira.pdf $>$. Accessed 11 January 2014.

IPNI. 2013. The International Plant Names Index. <http:// www.ipni.org>. Accessed 23 December 2013.

JONES MM, FERRIER S, CONDIT R, MANION G, AGUILAR S AND PÉREZ R. 2013. Strong congruence in tree and fern community turnover in response to soils and climate in central Panama. J Ecol 101: 506-516.

JONES MM, SZYSKA B AND KESSLER M. 2011. Microhabitat partitioning promotes plant diversity in a tropical montane forest. Global Ecol Biogeogr 20: 558-569.

KURTZ BC AND ARAÚJO DSD. 2000. Composição florística e estrutura do componente arbóreo de um trecho de Mata Atlântica na Estação Ecológica Estadual do Paraíso, Cachoeiras de Macacu, Rio de Janeiro, Brasil. Rodriguésia 51: 69-111.

LEGENDRE P AND GALLAGHER ED. 2001. Ecologically meaningful transformations for ordination of species data. Oecologia 129: 271-280.

MAGURRAN AE. 2004. Measuring biological diversity. Oxford: Wiley-Blackwell, $215 \mathrm{p}$.

MARTINS FR. 1993. Estrutura de uma floresta mesófila. Campinas: Editora UNICAMP, 246 p.

MATTOS CLV. 2005. Caracterização climática da Restinga da Marambaia. In: Menezes LFT, Peixoto AL and Araújo DSD (Eds), História Natural da Marambaia. Seropédica: Editora da Universidade Rural, p. 55-66.

MORO MF AND MARTINS FR. 2011. Métodos de levantamento do componente arbóreo-arbustivo. In: Felfili JM et al. (Eds), Fitossociologia no Brasil: Métodos e Estudos de Caso. Viçosa: Editora da Universidade Federal de Viçosa, p. 174-212.

MUELLER-DOMBOIS D AND ELLENBERG H. 1974. Aims and methods of vegetation ecology. New York: J Wiley \& Sons, $547 \mathrm{p}$.

MURRAY-SMITH C, BRUMMITT NA, OLIVEIRA-FILHO AT, BACHMAN S, MOAT J, LUGHADHA EM AND LUCAS EJ. 2009. Plant diversity hotspots in the Atlantic coastal forests of Brazil. Conserv Biol 23: 151-163.

MYERS N, MITTERMEIER RA, MITTERMEIER CG, DA FONSECA GAB AND KENT J. 2000. Biodiversity hotspots for conservation priorities. Nature 403: 853-858.

NETTESHEIM FC, DAMASCENO ER AND SYLVESTRE LS. 2014. Different slopes of a mountain can determine the structure of ferns and lycophytes communities in a tropical forest of Brazil. An Acad Bras Cienc 86: 199-210.

NETTESHEIM FC, MENEZES LFT, CARVALHO DC, CONDE MMS AND ARAUJO DSD. 2010. Influence of environmental variation on Atlantic Forest tree-shrublayer phytogeography in southeast Brazil. Acta Bot Bras 24: 369-377. 
NETTESHEIM FC, MENEZES LFT, CARVALHO DC, CONDE MMS, SOMNER GV, RODRIGUES GA AND ARAUJO DSD. 2012. Tree and shrub species of the Atlantic Forest on the slopes of Marambaia Island, Rio de Janeiro, Brazil. Biota Neotrop 12: 213-225.

OKSANEN J, BLANCHET FG, KINDT R, LEGENDRE P, MINCHIN PR, O'HARA R, SIMPSON GL, SOLYMOS P, STEVENS MHH AND WAGNER H. 2014. Package "vegan", Community Ecology Package. R package version 2.2-1. <http://CRAN.R-project.org/package=vegan $>$. Accessed 12 March 2014.

OLIVEIRA AES, KURTZ BC AND CREED JC. 2008. Fitossociologia e Produção de Serrapilheira em um Trecho de Mata Atlântica, no Município de Angra dos Reis, RJ. Rev Biol Farm 2: 1-19.

OLIVEIRA-FILHO AT, BUDKE JC, JARENKOW JA, EISENLOHR PV AND NEVES DRM. 2013. Delving into the variations in tree species composition and richness across South American subtropical Atlantic and Pampean forests. J Plant Ecol 6: 1-23.

OLIVEIRA RR. 2002. Ação antrópica e resultantes sobre a estrutura e composição da Mata Atlântica na Ilha Grande, RJ. Rodriguésia 53: 33-58.

OLIVEIRA RR AND ENGEMANN C. 2011. História da paisagem e paisagens sem história: a presença humana na Floresta Atlântica do Sudeste Brasileiro. Esboços 18: 9-31.

OLIVEIRA-FILHO AT AND FONTES MAL. 2000. Patterns of Floristic Differentiation among Atlantic Forests in Southeastern Brazil and the Influence of Climate. Biotropica 32: 793-810.

PEREIRA LA, XEREZ R AND PEREIRAAMC. 1990. Ilha da Marambaia (Baía de Sepetiba, RJ): Resumo fisiográfico, histórico e importância ecológica atual. Cien Cult 42: 384389.

R CORE TEAM. 2014. R: A language and environment for statistical computing. Vienna, Austria, R Foundation for Statistical Computing. https://www.R-project.org/.

RAMBALDI DM, MAGNANI A, ILHA A, LARDOSA E, FIGUEIREDO F AND OLIVEIRA RF. 2003. A Reserva da Biosfera da Mata Atlântica no Estado do Rio de Janeiro. Conselho Nacional da Reserva da Biosfera da Mata Atlântica. <http://www.rbma.org.br/rbma/pdf/ Caderno_22.pdf $>$. Accessed 02 January 2014.

ROBERTS DW. 2013. Package "labsdv", Ordination and Multivariate Analysis for Ecology. R package version 1.61. < http://cran.r-project.org/web/packages/labdsv/index. html $>$. Accessed 13 March 2014.

ROCHELLE ALC, CIELO-FILHO R AND MARTINS FR. 2011, Tree community structure in an Atlantic forest fragment at Serra do Mar State Park, southeastern Brazil. Biota Neotrop 11: 337-346.

RODRIGUES RMM AND MAGALHÃES LMS. 2011. Estrutura e Florística de Fragmento de Floresta Secundária na Planície Aluvionar do Rio Guandu, em Seropédica-RJ. Floresta Ambient 18: 324-333.

RODRIGUES RRR, GANDOLFI S, NAVE AG, ARONSON J, BARRETO TE, VIDAL CY AND BRANCALION PHS. 2011. Large-scale ecological restoration of highdiversity tropical forests in SE Brazil. Forest Ecol Manag 261: 1605-1613.

SANTANA CAA, LIMA CCD AND MAGALHÃES LMS. 2008. Estrutura horizontal e composição florística de três fragmentos secundários na cidade do Rio de Janeiro. Acta Sci Biol Sci 26: 443-451.

SCARANO FR. 2002. Structure, function and floristic relationships of plant communities in stressful habitats marginal to the Brazilian Atlantic Rainforest. Ann Bot 90: 517-524.

SCUDELLER VV, MARTINS FR AND SHEPHERD GJ. 2001. Distribution and abundance of arboreal species in the atlantic ombrophilous dense forest in Southeastern Brazil. Plant Ecol 152: 185-199.

SEIFERLING I, PROULX R AND WIRTH C. 2014. Disentangling the environmental heterogeneity-species diversity relationship along a gradient of human footprint. Ecology 95: 2084-2095.

SILVA DF, OLIVEIRA CM, NOBREGA LA, MENDES FF AND OLIVEIRA OC . 2008. Grupos caiçaras na Ilha da Marambaia, RJ: atores externos, conflitos e transformações econômicas. Perspec Contemp 3: 73-90.

SOLÓRZANO A, GUEDES-BRUNI RR AND OLIVEIRA RR. 2012. Composição florística e estrutura de um trecho de floresta ombrófila densa atlântica com uso pretérito de produção de banana, no parque estadual da Pedra Branca, Rio de Janeiro, RJ. Rev Arvore 36: 451-462.

SOUZA CRG, SUGUIO K, OLIVEIRA MAS AND OLIVEIRA PE. 2005. Quaternário do Brasil. Ribeirão Preto: Holos Editora, 382 p.

SPIEGEL MR. 1976. Estatística. São Paulo: McGraw-Hill, $580 \mathrm{p}$.

TILMAN D, MAY RM, LEHMAN CL AND MA NOWAK. 1994. Habitat destruction and the extinction debt. Nature 371: 65-66.

TONHASCA JR A. 2005. Ecologia e história natural da Mata Atlântica. Rio de Janeiro: Editora Interciência , 197 p.

WERNECK MS, SOBRAL MEG, ROCHA CTV, LANDAU EC AND STEHMANN JR. 2011. Distribution and endemism of angiosperms in the Atlantic forest. Nat Conservacao 9: 188-193.

WHITMORE TC. 1990. An introduction to tropical rain forests. Oxford: Oxford University Press, 226 p.

YABETA D AND GOMES F. 2013. Memória, cidadania e direitos de comunidades remanescentes (em torno de um documento da história dos quilombolas da Marambaia). Afro-Ásia 47: 79-117. 


\section{SUPPLEMENTARY MATERIAL}

Figure S1 - Diameter distribution of the sampled individuals in the Atlantic Rainforest tree community on the continental island of Marambaia. The horizontal axis represents the diameter classes center and the vertical axis represents the number of individuals in each diameter class.

TABLE SI - List of the Atlantic Rainforest tree community species found at the continental island of Marambaia and their respective abundances in each of the sampled sites. $\mathrm{A}=$ Northwest site; $\mathrm{B}=$ Southwest site; $\mathrm{C}=$ Southeast site.

TABLE SII - Phytosociological parameters for the species in the Atlantic Rainforest tree community on the continental island of Marambaia. Species are presented according to decreasing importance value in the community. $\mathrm{Ni}=$ number of individuals; $\mathrm{Rd}=$ relative density; $\mathrm{Rf}=$ relative frequency; Rdom $=$ relative dominance; $\mathrm{IV}=$ importance value.

TABLE SIII - Phytosociological parameters of the families in the Atlantic Rainforest tree community on the continental island of Marambaia. Families are presented according to decreasing importance value in the community. $\mathrm{Ni}=$ number of individuals; $\mathrm{RD}=$ relative density; $\mathrm{RF}=$ relative frequency; Rdom = relative dominance; $\mathrm{IV}=$ importance value.

TABLE SIV - Results of the Games-Howell post-hoc test to compare the mean values of Atlantic Rainforest tree community abundance, richness, total basal area and diversity between sites $\mathrm{A}, \mathrm{B}$ and $\mathrm{C}$ at the continental island of Marambaia. $\mathrm{t}=$ values for the ANOVA statistic; $d f=$ degrees of freedom; $p=$ p-value. 